\title{
A educação infantil como projeto da comunidade: crianças, educadores e pais nos novos serviços para a infância e a família: a experiência de San Miniato
}

\author{
FORTUNATI, Aldo. Tradução ROSA, Ernani. Porto Alegre:
} Artmed, 2009. 204 p.

M arta Regina Paulo da Silva*

\begin{abstract}
Eu também me perguntei, em uma mistura de ansiedade e temor, se aquela escolha seria realmente justa.

Assim, na sala onde as educadoras recebiam os pais durante os primeiros dias, me dediquei a aguçar o ouvido para comprovar se meus filhos choravam, ficando sobressaltada cada vez que ocorria um barulho diferente. Enfim, estava procurando sinais com que pudesse avaliar e que me servissem de garantia de que tudo corria beml.
\end{abstract}

A presentar um livro, neste caso, A educação infantil como projeto da comunidade: crianças, educadores e pais nos novos serviços para a infância e a família: a experiência de San M iniato, é "dá-lo a ler, dá-lo como um presente, compartilháIo" (Larrosa, 2004, p. 7). É isto que nos faz Aldo Fortunati, psicopedagogo, pesquisador da infância, presidente do Centro de Pesquisa e de D ocumentação sobre a infância La Bottega di Geppetto, da prefeitura de San M iniato, e vicepresidente do Gruppo N acionale N indi-infanzia. Ele nos presenteia com esta obra, publicada originalmente sob o título L'Educazione dei bambini come progetto della comunitá, em 2006, ano em que se comemoraram os vinte e cinco anos da rede de creche pública municipal de San M iniato.

A obra é um presente, uma vez que nos possibilita conhecer um programa educacional que, tendo como principais fundamentos de sua proposta "0 protagonismo da infância, o caráter aberto e colegial do trabalho educacional e

\footnotetext{
* D outoranda do Programa de Pós-Graduação da Faculdade de Educação da U nicamp, Campinas, SP, Brasil.martarps@uol.com.br

1. Depoimento de Monica, mãe de N iccolò e Cosimo (Fortunati, 2009, p. 197).
} 
a ampla margem que se dedica a conseguir a participação das famílias" (Fortunati, 2009, p. 102), vem construindo uma pluralidade de ofertas de serviços educacionais destinados às diferentes necessidades e demandas das crianças e das famílias.

Como um presente que nos é dado a abrir, desvelar, começo sua apresentação pelo apêndice, "Lembranças e testemunhos de uma história de empenhos e paixões", com a epígrafe que narra parte do depoimento de M onica, que fala da angústia e da dificuldade em deixar pela primeira vez seus filhos na escola de Educação Infantil, embora entendesse ser isso importante para eles. Relato que se entrelaça a outros depoimentos que narram a luta das mulheres italianas por espaços educacionais que atendessem seus filhos/as com idade entre zero e 3 anos, num momento histórico marcado pela ideia de que as crianças pequenas deveriam ser educadas por suas famílias. Luta que, por sua vez, entremeiase a tantas outras lutas, de tantas outras mulheres, em diferentes contextos históricos. Enfim... lutas, dúvidas, contradições, conflitos, conquistas... que marcaram estas últimas décadas, em que novas formas de ver e pensar as crianças e a infância vêm sendo construídas.

A experiência de San M iniato constitui-se em um exemplo concreto de que é possível olhar crianças e famílias com outras lentes, como protagonistas do processo educacional, o que terá como consequência uma redefinição do papel do/a educador/a em seu pensar e fazer pedagógico, bem como outra compreensão dos espaços destinados à infância. D e diferentes perspectivas, este é o aspecto tratado nos quatro prefácios que compõem o livro: 0 da edição brasileira, escrito pela Profa Ana Lucia Goulart de Faria; o da versão espanhola, pela Profa Irene Balaguer; o da edição inglesa, pelo Profo Peter M oss; e, finalmente, o prefácio da publicação italiana, pela Profa Susanna M antovani.

Percorrendo esses prefácios, vamos não apenas nos familiarizando com a proposta de San M iniato, mas também refletindo sobre nossas próprias imagens acerca das crianças, da infância e da Educação Infantil. Reflexão alimentada por suas duas introduções e, de modo especial, pelo ensaio introdutório "Educação e mudança: apontamentos e oportunidades de reflexão sobre as crianças e sobre os modos de educar", do próprio Fortunati, que denuncia não apenas os discursos e as políticas públicas para a infância que subestimam a capacidade das crianças e das famílias, mas também o perigo de uma distorção do sentido da "competência da criança", "transformando a consciência da precocidade da expressão das potencialidades em uma pressão para preconizar aprendizagens e rendimentos, em uma espécie de corrida para sair da infância o mais rápido possível" (p. 36).

Ao considerar as crianças como sujeitos competentes, curiosos, ativos, interativos, é preciso respeitar seus diferentes tempos e ritmos pessoais e, nesse 
sentido, repensar o trabalho docente de forma a construir experiências mais significativas com elas, abandonando projetos caracterizados por orientações meramente prescritivas. Assim, o papel do/a educador/a "se desenvolve muito mais sobre a organização de contextos estruturantes que sobre a proposta de estímulos diretos no fazer das crianças, muito mais sobre a capacidade de reconhecimento e expansão das diversidades dos estilos de condutas das crianças que sobre a ânsia de conduzi-las para atuações precisas e pré-definidas" (p. 38). Desse modo, os serviços destinados à infância devem abrir-se à dimensão do diálogo e da participação de todos/as os/as envolvidos/as no processo educacional. D imensões que estão explicitadas nas três partes que compõem o livro: "O s pensamentos e as ações que sustentam a ação educacional", "O s serviços educacionais para a infância de San M iniato" e "Temas e documentos da exposição Por uma ideia de criança".

$\mathrm{N}$ a primeira parte, "O s pensamentos e as ações que sustentam a ação educacional", é possível visualizar a tríade crianças, educadores/as e famílias, na construção de espaços que possibilitem às crianças momentos de experiências compartilhadas entre si, com os/as educadores/as e com as famílias, seja nos momentos de transição da família para escola, como, por exemplo, o período de adaptação, seja no convívio cotidiano, em diferentes ambientes intencionalmente organizados para que as crianças explorem, observem, interajam, inventem, brinquem... Aqui, o papel do planejamento, da observação, da documentação e da avaliação por parte dos adultos é fundamental, no intuito de refletir acerca das hipóteses de trabalho e, consequentemente, rever processos. Além da gestão dos espaços educativos, os educadores/as são responsáveis também pelas relações com os demais serviços para a infância e com a prefeitura.

Ainda nesta primeira parte, nos é dado conhecer como se organiza a gestão integrada dos serviços para a infância, cuja ênfase recai na centralidade da participação das famílias e no seu envolvimento na gestão social dos serviços. Família e escola são compreendidas como instituições complementares na educação das crianças. Segundo Fortunati, "a participação das famílias não é um elemento acessório - mas fundamental - no projeto de um serviço educacional" (p. 181). Com isso, no intuito de acolher cada vez mais crianças e famílias em espaços que atendam a suas demandas e necessidades, San M iniato tem oferecido a elas uma rede integrada e com diversificada oferta de serviços, o que pressupõe diálogo e flexibilidade nas formas de gestão, que envolvem tanto 0 poder público como o privado.

Essas formas de atendimento são exemplificadas na segunda parte do livro, "O s serviços educacionais para a infância de San M iniato", onde são apresentadas algumas informações históricas, culturais e socioeconômicas de San M iniato, bem como algumas escolas de Educação Infantil, a área de encontro e brinca- 
deira "II Paese dei balocchi" ("O país dos brinquedos") e o Centro de Pesquisa e Documentação sobre a Infância "La bottega di Geppetto" ("A oficina de G eppeto"). N a apresentação de cada uma dessas instituições, há a descrição de sua estrutura de funcionamento, formas de gestão e planta arquitetônica, além de fotos que permitem uma noção da organização dos espaços físicos, que demonstram, no caso das escolas, atenção e cuidado para que as crianças se possam "orientar com suas próprias bússolas" (p. 151); e, no caso do "País dos brinquedos", revelam uma área de encontro onde pais/mães e crianças podem brincar e também compartilhar suas experiências sobre ser pai/mãe, sobre infância e educação.

Finalmente, na terceira parte do livro, "Temas e documentos da exposição Por uma ideia de criança", deliciamo-nos com belíssimas fotos das crianças em ação, em diferentes situações que compõem seu cotidiano, o que Fortunati chama de "itinerários de experiência individual e compartilhada".

Eis a experiência educativa de San $M$ iniato relatada neste livro por Aldo Fortunati. Uma leitura instigante para educadores/as, gestores/as e políticos. Uma leitura não na expectativa de ali encontrar respostas às questões e aos desafios relacionados aos serviços destinados à infância no Brasil, mas como um alimento à nossa esperança, à nossa utopia de construir espaços que efetivamente respeitem as crianças pequenas em seus direitos. Em tempos marcados pelo empobrecimento das experiências humanas, pelo esfacelamento das relações sociais, pelo aceleramento da vida..., nada melhor do que acreditar na construção de outro mundo possível e lutar por ela. Sendo assim, que a experiência de "San M iniato" seja mais uma inspiração para um Brasil que, respeitando as culturas locais, possa criar uma multiplicidade de serviços para infância, marcados, sobretudo, pela alegria, pela curiosidade e pela inventividade de seus protagonistas, as crianças brasileiras.

\section{Referência bibliográfica}

LARRO SA, Jorge. Linguagem eeducação depoisdeBabel. Belo H orizonte: Autêntica, 2004. (Educação: experiência esentido) 